\title{
The association between corporate social responsibility reporting and firm value for South African firms
}

\begin{tabular}{|c|c|}
\hline \multicolumn{2}{|c|}{$\begin{array}{l}\text { Authors: } \\
\text { Riana Horn }{ }^{1} \text { (1) } \\
\text { Marna de Klerk } \\
\text { Charl de Villiers } \\
\text { 2,3 }\end{array}$} \\
\hline \multicolumn{2}{|c|}{$\begin{array}{l}\text { Affiliations: } \\
{ }^{1} \text { Department of Financial } \\
\text { Accounting, University of } \\
\text { South Africa, South Africa }\end{array}$} \\
\hline \multicolumn{2}{|c|}{$\begin{array}{l}{ }^{2} \text { Department of Accounting, } \\
\text { University of Pretoria, } \\
\text { South Africa }\end{array}$} \\
\hline \multicolumn{2}{|c|}{$\begin{array}{l}{ }^{3} \text { Graduate School of } \\
\text { Management, University } \\
\text { of Auckland, New Zealand }\end{array}$} \\
\hline \multicolumn{2}{|c|}{$\begin{array}{l}\text { Corresponding author: } \\
\text { Riana Horn, } \\
\text { hornrh@unisa.ac.za }\end{array}$} \\
\hline \multicolumn{2}{|c|}{$\begin{array}{l}\text { Dates: } \\
\text { Received: } 16 \text { Dec. } 2017 \\
\text { Accepted: } 17 \text { May } 2018 \\
\text { Published: } 28 \text { Aug. } 2018\end{array}$} \\
\hline \multicolumn{2}{|c|}{$\begin{array}{l}\text { How to cite this article: } \\
\text { Horn, R., De Klerk, M. \& De } \\
\text { Villiers, C., 2018, 'The } \\
\text { association between } \\
\text { corporate social responsibility } \\
\text { reporting and firm value for } \\
\text { South African firms', } \\
\text { South African Journal of } \\
\text { Economic and Management } \\
\text { Sciences } 21(1) \text {, a2236. https:// } \\
\text { doi.org/10.4102/sajems. } \\
\text { v21i1.2236 }\end{array}$} \\
\hline \multicolumn{2}{|c|}{$\begin{array}{l}\text { Copyright: } \\
\text { (C) 2018. The Authors. } \\
\text { Licensee: AOSIS. This work } \\
\text { is licensed under the } \\
\text { Creative Commons } \\
\text { Attribution License. }\end{array}$} \\
\hline \multicolumn{2}{|l|}{ Read online: } \\
\hline 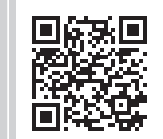 & $\begin{array}{l}\text { Scan this QR } \\
\text { code with your } \\
\text { smart phone or } \\
\text { mobile device } \\
\text { to read online. }\end{array}$ \\
\hline
\end{tabular}

Background: Corporate social responsibility (CSR) disclosure is widespread among the largest companies in South Africa due to the listing requirements of the Johannesburg Stock Exchange (JSE). These companies have also increasingly pursued external assurance of their CSR disclosures in recent years. The increased regulation of CSR disclosure and the increased rate of obtaining assurance of these disclosures motivated us to perform our study.

Aim: To examine the association between CSR reporting, including both CSR disclosure and CSR assurance, and firm value of large South African companies.

Setting: The JSE listing requirements place South Africa, the setting for our study, at the forefront of corporate governance and CSR reporting.

Method: Tobin's Q is used as a measure of firm value. Three measures of CSR disclosure and three of CSR assurance are used in this study. The measures are based on data collected by Klynveld Peat Marwick Goerdeler (KPMG) International on the CSR reporting practices of large South African companies. The sample period for this study coincides with the sample period covered in the KPMG surveys conducted during 2008, 2011 and 2013.

Results: No significant association is found between CSR disclosure and firm value. However, a significant negative association is found between CSR assurance and firm value. Additional analysis found that the negative association between firm value and CSR assurance is more significant for companies that are not listed on the Socially Responsible Investment (SRI) index.

Conclusion: The results found between CSR disclosure and firm value may suggest that firm value is unaffected by CSR disclosures. Taken together, the findings on CSR assurance and firm value and the additional analysis may suggest that in South Africa managers with negative CSR issues are more likely to obtain assurance on their CSR disclosure. The findings may be of interest to regulators when considering current and future disclosure and assurance requirements for CSR reporting in South Africa, as well as other parts of the world, shareholders when considering investment options, and managers when considering the benefit of certain CSR reporting practices.

\section{Introduction}

The King Code of Governance Principles, the King Report on Governance (KING III) and the Johannesburg Securities Exchange (JSE) requirements place South Africa at the forefront of corporate governance and corporate social responsibility (CSR) reporting. The JSE was the first exchange to incorporate King into the listing requirements for financial years starting on or after 01 March 2010, thereby mandating that companies either apply integrated reporting or explain non-compliance (De Villiers, Hsiao \& Maroun 2017; JSE 2013a). Integrated reporting entails the disclosure of both the company's financial and sustainability (also referred to as CSR) performances (Dumay \& Dai 2017; Dumay et al. 2017; King Committee 2009). Disclosures should consider the economic, social and environmental result of the company's operations (King Committee 2009; Macias \& Farfan-Lievano 2017; McNally, Cerbone \& Maroun 2017). Mandatory CSR reporting requirements in South Africa have resulted in a 98\% CSR reporting rate among the 100 largest companies surveyed by Klynveld Peat Marwick Goerdeler (KPMG) during 2013 (KPMG 2013). The rate of CSR reporting in 2013 is consistent with the 2011 rate of $97 \%$ but represents a considerable increase from the 2008 rate of $45 \%$ (KPMG 2011). Compliance with some form of CSR reporting comprising mostly non-financial information about the impact of social and environmental change and strategies employed by companies is prescribed in South Africa. To manage the related risks and opportunities (De Klerk, De Villiers \& Van Staden 2015; KPMG 2013), the extent and detail of these disclosures is not prescribed since it is mandated to 'apply or explain' (Du Toit, Van Zyl \& Schutte 2017; JSE 2013b). Therefore, even in this environment of mandated CSR reporting, the 'what' and the 'how much' are still left to the discretion of management. 
The KPMG International Survey of Corporate Responsibility Reporting for 2013 indicates that only France and South Africa are forging a mandatory approach to obtaining external assurance of the CSR report. Companies were mainly found to be motivated to obtain voluntary assurance to demonstrate credibility, to meet the requirements of sustainability indices, and to create possible internal value through more reliable data and better insight into CSR issues (KPMG 2013). Both O'Dwyer and Owen (2005) and Park and Brorson (2005) found these assurance statements to represent a managerial tool rather than enhanced credibility. The report on the KPMG international survey (2008, 2011, and 2013) indicates an increase in the 100 largest companies in South Africa seeking third-party assurance of their sustainability reports from 16\% in 2008 to $30 \%$ in 2011 to $43 \%$ in 2013.

Firm value incorporates both the firm's future cash flow and the assessed inherent risk reflected in the discount rate (i.e. cost of capital) (De Villiers \& Marques 2016). Any potential benefit manifested as a financial consequence associated with CSR can be expected to be included by market participants when they assess the firm's future prospects and associated risks. Firm value represents a measure similar to market value and is widely used as a proxy for the latter (Jiao 2011). Firm value highlights the incremental portion of the market price that exceeds the book value. We examine the association between CSR reporting (focusing on disclosure and assurance), and the long-term expected value of the firm by employing a Tobin's Q model (Cahan et al. 2016).

We aim to contribute to the current debate by responding to the call made by De Klerk and De Villiers (2012) to refine the CSR measures and extend the assessment period. De Klerk and De Villiers (2012) point to the possibility that the effect of CSR disclosure, and possibly also CSR assurance, is context specific. A further possibility is that the effect is period specific. The instinctive expectation may be that the association between CSR and firm value will strengthen as regulation and public awareness increase over time. However, an alternative expectation may be that the association will weaken as CSR becomes regulated and routine. We incorporate more refined measures for CSR disclosure and also of CSR assurance, over a more recent period. To measure CSR, we use survey data prepared by KPMG International, an external organisation, for three periods, namely 2008, 2011 and 2013. The survey data text is converted to quantifiable measures to determine CSR. The use of the KPMG external rating (the first report was published in 1993) is considered more reliable and stable than a self-constructed disclosure index and is widely accepted in literature and business (Cahan et al. 2016; De Klerk \& De Villiers 2012; De Klerk et al. 2015).

We contribute to the literature in several ways. Firstly, to our knowledge this is the first comprehensive analysis of the association between CSR disclosure and assurance and firm value in South Africa. Secondly, we use data from more recent periods over an extended period, namely mid-2007 to mid-2008, mid-2010 to mid-2011, and mid-2012 to mid-2013. Thirdly, we use data collected by an independent accounting firm (KPMG) to construct six measures for CSR reporting.
Three variables measure trends in CSR disclosure, and three variables measure trends in assurance of CSR reports. Finally, to our knowledge this is the first study conducted in South Africa that additionally tests for the robustness of its findings by attempting to both control for CSR performance and separating the sample into two groups: sample companies listed on the Socially Responsible Investment (SRI) ${ }^{1}$ index, and sample companies not listed on the SRI index. The SRI index is used as a proxy for CSR performance.

Our results for the main analysis, as well as the additional tests, do not support our expectation of a significant association between CSR disclosure and firm value, which might indicate that both the regulation of disclosure and the high rate of disclosure among companies in South Africa have a limiting effect on the significant association found in previous literature. Cahan et al. (2016) refer to the possibility that the informative value of CSR disclosure might be reduced because the market has less information to assess the potential and risk of a company relative to its industry peers. A significant negative association is found between two of the three measures of CSR assurance and firm value. The results of the additional tests suggest that the negative association between firm value and CSR assurance is more significant for companies that are not listed on the SRI index. The results are supported by the findings of Simnett, Vanstraelen and Chua (2009), who indicate that the choice by companies to obtain voluntary CSR assurance could be ascribed to an attempt to enhance the CSR credibility of a company. The findings of our study may be of interest to regulators and the JSE when considering current and future regulations, shareholders when considering investment choices, and managers considering the cost versus benefit of providing CSR disclosure and CSR assurance. The findings may also be of interest to regulators in other parts of the world who are considering mandating CSR reporting (i.e. CSR disclosure and CSR assurance).

The remainder of the article is structured as follows: In the 'Prior literature and development of hypotheses' section, the existing literature on the relationship between CSR reporting and the economic and financial consequences is explored and the hypotheses are developed. In the 'Sample, data, and research method' section, details are provided regarding the sample, data sources, the measures of CSR reporting, and the research method. The results are then presented, as well as a conclusion, where suggestions are made regarding possible related research in the future.

\section{Prior literature and development of hypotheses Background}

Rising interest regarding the natural environment and the responsibilities of companies as corporate citizens and their economic, social and environmental performance may cause

\footnotetext{
1.The Johannesburg Stock Exchange (JSE) introduced the JSE Socially Responsibi Investment (SRI) index in 2004 to (JE) introduced the JSE Socially Responsible and transparent (JSE 2014). Companies included on the FTSE/JSE All Share index are assessed annually against environmental, social and governance criteria for inclusion on the SRI index (JSE 2014).
} 
shareholders to require more accountability for environmental and social issues from the companies (management) in which they invest (De Villiers \& Van Staden 2011b; King Committee 2009). CSR information, as disclosed by management, can affect firm value by either enabling better prediction of future cash flow, or reducing cost of capital (Clarkson et al. 2013), as it confirms a company's commitment to communicating its long-term performance and risk management strategies (Dhaliwal et al. 2011) to shareholders. A survey conducted by Kamala, Wingard and Cronje (2016) found that $83 \%$ of the sampled users had read an environmental report in the past calendar year. CSR reporting (both disclosure and assurance) provides shareholders with information that is not readily available from other sources, which allows them to assess possible strategic opportunities (De Klerk et al. 2015). The extant literature generally suggests a negative association between cost of equity capital and CSR (Dhaliwal et al. 2011, 2014; Reverte 2012). We seek to contribute by examining the anticipated value of CSR reporting through testing for an association between CSR reporting (both disclosure and assurance) and firm value.

We use the concept of information asymmetry from the agency theory as applied in the voluntary disclosure literature (De Klerk \& De Villiers 2012; De Klerk et al. 2015). With this we examine the usefulness of management's CSR reporting in providing incremental information about companies' risks and future performance and their management strategies thereof to shareholders to better enable them to estimate firm value in making investment decisions. Agency theory posits that information asymmetry exists where there is separation of ownership (shareholders) and control (managers). We argue that the information asymmetry considerations affect the 'what' and the 'how much' CSR reporting discretion of management. Ownership (shareholders) information needs arguably incorporate information about the company's CSR practices to enable them to assess long-term investment opportunities. A South African survey conducted by De Villiers and Van Staden (2010) found individual shareholders to be interested in the disclosure of environmental risks, impacts, policy, targets, subsequent performance and costs. A study performed by Turyakira, Venter and Smith (2014) indicates a positive association between CSR activities associated with the workforce, society, the market and regulation and increased competitiveness. However, a negative association was found to exist between CSR activities relating to the environment and increased competitiveness (Turyakira et al. 2014). Shareholders may either be less able to predict future cash flow and profitability or require a higher rate of return on investment if they do not have relevant information, which affects firm value (Clarkson et al. 2013).

\section{Prior research exploring expected financial consequences of corporate social responsibility disclosure and hypothesis development}

An association between CSR disclosure and firm value is expected if CSR disclosure conveys incremental information about companies' current and future environmental risks and opportunities (Clarkson et al. 2013). Choi, Kwak and Choe (2010) investigated the association between CSR performance, measured by a stakeholder-weighted Korea Economic Justice Institute index, and financial performance, measured by return on equity, return on assets and Tobin's Q. They found a significant positive association between their measures of financial performance and their measure of CSR performance, which suggests that companies align their CSR activities with the activities most valued by their primary stakeholders (Choi et al. 2010). A similar study conducted in 2010, using the KLD as a stakeholder score, also found a positive association with Tobin's Q, driven mainly by employee relations and environmental issues (Jioa 2010). Jiao (2011) then examined the association between both voluntary and mandatory corporate disclosures and firm value (and stock returns) and found that the results indicate a positive association between their disclosure rating and Tobin's Q (and stock returns), suggesting a sincere effort by management to communicate positive information about future earnings to stakeholders. A positive association between unexpected CSR disclosure and firm value, as measured by Tobin's $Q$, is observed in Cahan et al.'s cross-country investigation (2016) of the incremental information included in CSR disclosures. No association is found between expected CSR disclosure and firm value.

Shareholders require information about the environmental risks involved in a company's operations (Al-Tuwaijri, Christensen \& Hughes 2004; De Villiers \& Van Staden 2010) and management's response to these risks (Clarkson et al. 2008; De Villiers \& Van Staden 2010) to assure them of the company's profitability and their investment value. Following agency theory, managers have an incentive to provide higher levels of CSR disclosure in order to decrease the information asymmetry and increase firm value. Hypothesis 1 is stated in the alternate:

H1: CSR disclosure levels are positively associated with firm value.

The limited number of existing studies that examine the association between CSR disclosure and firm value as measured by Tobin's $Q$ serves as motivation for further investigation.

\section{Prior research exploring expected financial consequences of corporate social responsibility assurance and hypothesis development}

The 2013 KPMG survey report indicates that in 2013, 59\% of the 250 largest global companies reporting CSR chose to obtain external assurance of their report. This is a substantial increase from the $46 \%$ and $40 \%$ respectively of companies reporting on CSR that had their reports externally assured in 2011 and 2008. The 100 companies reporting the highest revenue in South Africa have also increasingly sought thirdparty assurance of their sustainability reports. Data from the KPMG international survey (2008, 2011, and 2013) indicate that, in $2008,16 \%$ of these companies obtained third-party 
assurance, with subsequent increases to 30\% in 2011 and 43\% in 2013. O'Dwyer and Owen (2005) analysed assurance statements of environmental, social, and sustainability reports to gain an understanding of the extent to which these reports increase transparency and accountability. They found that assurance statements are not used as a stakeholder accountability control, but rather as a managerial tool to make an internal assurance exercise public. In fact, interview data from a Swedish study indicate that companies view third-party assurance as useful for developing internal reporting systems, but not for increasing credibility (Park \& Brorson 2005). An international research project focusing on the content of triple bottom line (TBL) report assurance statements in Europe and the United Kingdom (UK) further demonstrates that uncertainty and inconsistency in current assurance practices undermine the desired transparency and accountability, and the project ultimately expresses doubt about whether assurance adds value to the TBL report (Deegan, Cooper \& Shelly 2006). A South African survey found that users ranked the improvement of the reliability of environmental reports, with specific reference to independent verification, as highly important (Kamala et al. 2016). Simnett et al. (2009) examined the emergent voluntary assurance of sustainability reports market and found that companies with a greater need to enhance the credibility of their sustainability reports are more likely to seek assurance.

Companies (and thus their managers) have a choice of whether or not to obtain third-party assurance of their CSR reports. As the level of disclosure is at the discretion of managers, obtaining third-party assurance may have a limited effect on enhancing the credibility of these disclosures, as the assurance market is still plagued by inconsistencies (Deegan et al. 2006). A second possibility is that obtaining assurance of the CSR report is positively associated with firm value, as the market views the choice to obtain assurance as enhancing value. De Villiers and Van Staden's (2010) survey results indicate that $75 \%$ of shareholders in the South African study want environmental information to be audited in order to improve the reliability thereof. A third possibility is that assurance is obtained only by companies (managers) with negative CSR issues, which will result in a negative association between assurance and firm value. Simnett et al. (2009) found that a company's choice to obtain voluntary CSR report assurance is likely made when a company has pre-existing credibility issues. As companies (managers) that choose to obtain third-party assurance of their CSR report may do so either to signal credibility to the market, or to mask credibility issues from the market, we refrain from forming an expectation regarding the direction of the association between the CSR assurance measures and firm value. Hypothesis 2 is stated in the null:

H2: Obtaining third-party assurance of the CSR report is not associated with firm value.

The current trend observed in the market, which shows that companies increasingly choose to obtain third-party assurance of their CSR reports, justifies an investigation of the association between this emerging assurance market and firm value.
By examining whether there is a positive association between CSR disclosure and firm value, and whether the choice to obtain third-party assurance of the CSR report is not associated with firm value, we aim to contribute a comprehensive analysis on the association between CSR disclosure and assurance and firm value in South Africa to the literature.

\section{Sample, data, and research method Sample}

The sample consists of the 100 largest South African companies based on revenue, as identified by the KPMG Survey of Corporate Responsibility Reporting for 2008, 2011, and 2013. We exclude eight companies from the 2008 sample, one from the 2011 sample, and four from the 2013 sample on the grounds that those companies are unlisted entities. We further exclude eight companies from the 2008 sample and seven from each of the 2011 and 2013 samples for which we are unable to obtain financial data on the McGregor BFA database. We also exclude 14 companies from the 2008 sample, 13 from the 2011 sample, and 12 from the 2013 sample to control for the unique financial ratio characteristics of these banking and insurance companies. Finally, we exclude five companies from the 2008 sample, and four each from the 2011 and 2013 samples, for which trading data is not available on the Bureau van Dijk Orbis database. Our final sample consists of 65 companies for the mid-2007 to mid-2008 sample period, 75 companies for the mid-2010 to mid-2011 sample period, and 73 companies for the mid-2012 to mid-2013 sample period. The sample periods used in our study follow the periods used in the KPMG International Survey of Corporate Responsibility Reporting for 2008, 2011, and 2013, which examines CSR reporting practices (KPMG 2008, 2011, 2013).

\section{Data}

The KPMG International Survey of Corporate Responsibility Reporting for 2008, 2011, and 2013 is used to obtain data about the CSR reporting practices of the 100 largest South African companies based on revenue (KPMG 2008, 2011, 2013). KPMG performed a comprehensive study of company reporting on CSR performance using only publicly available information in annual financial reports, standalone CSR reports, and company websites (KPMG 2013).

Six measures for CSR reporting (based on the KPMG database for CSR) are used. Three of these measure CSR disclosure trends, and the remaining three measure the assurance of CSR report practices. The first measure of CSR disclosure (IntRep) measures the level of integration of CSR reporting in the annual report. We convert the level of integration of CSR reporting in the annual report by awarding a score of 3 for CSR reporting information that is included in both the directors' report and a separate section of the annual report, a score of 2 for CSR reporting information included only in a separate section or chapter of the annual report, a score of 1 for CSR reporting information included in only the directors' report, and a score of 0 if CSR reporting is not integrated into the annual report. The second measure of CSR disclosure 
(Global Reporting Initiative [GRI]) is an indicator variable that is set to 1 for companies using the GRI guidelines, and otherwise to 0 (De Klerk \& De Villiers 2012; De Klerk et al. 2015). The GRI guidelines represent the leading reporting framework for CSR reporting globally, as over $78 \%$ of the top 100 companies from the 41 countries included in the survey use the GRI guidelines for CSR reporting (KPMG 2013). In South Africa the trend continues, with 85 of the top 100 companies using the GRI guidelines for CSR reporting in the 2013 survey, which signifies an increase from $67 \%$ and $46 \%$ in the 2011 and 2008 surveys respectively (KPMG 2008, 2011, 2013). The third measure of CSR disclosure is a composite measure (CompDisc) of the extent of coverage in terms of CSR information provided, taking into account both the level of integration of CSR reporting information in the annual report of the company, and whether CSR reporting information is provided in a standalone CSR report or on the company website.

The first measure of CSR assurance (ASSdum) is an indicator variable set to 1 for companies with a formal third-party assurance statement, and otherwise to 0 . The second measure of CSR assurance (ASSscope) measures the scope of the formal assurance statement provided by the assurance provider. We convert the scope of the formal assurance statement by awarding a score of 3 to a whole-report scope, a score of 2 to a chapter scope, a score of 1 to indicators and, otherwise, a score of 0 . The third measure of CSR assurance is a composite measure (CompAss) of CSR assurance practices.

Financial data for the sample companies were obtained from the McGregor BFA and Bureau van Dijk Orbis databases.

\section{Research method}

\section{Firm value}

We examine whether higher levels of CSR reporting are associated with expected financial consequences as reflected in the firm value. Tobin's $Q$ measures firm value and reflects the market's assessment of risk and expected future performance (Dhaliwal et al. 2011). To address hypotheses 1 and 2 regarding the association between CSR disclosure or obtaining third-party assurance and firm value, we use the following Tobin's $Q$ model: $Q_{i, t}=\beta_{0}+\beta_{1} \operatorname{CSR}_{i, t}+\beta_{2}$ Size $_{i, t}+$ $\beta_{3}$ Stock_turnover $_{i, t}+\beta_{4}$ ROA $_{i, t}+\beta_{5}$ Capital_expenditure $_{i, t}+\beta_{6}$ Debt $_{i, t}$

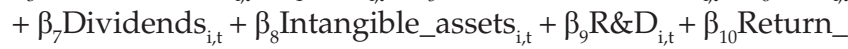
volatility $_{i, t}+\mathrm{Yr}+\varepsilon_{i, t}$

Tobin's $Q$ is the ratio of the market value of a firm's assets and can be regarded as both a performance measure and a measure of information asymmetry (De Villiers \& Van Staden 2011a). Q is measured as the market value of assets deflated by the book value of total assets, where the market value of assets is calculated as the sum of the book value of assets and the market value of common stock, less the book value of common stock and book value of deferred taxes (Cahan et al. 2016; Roll, Schwartz \& Subrahmanyam 2009). The control variables included in the equation are consistent with those used by Cahan et al. (2016), as based on prior literature (Coles, Daniel \& Naveen 2008; Jiao 2011; Roll et al. 2009). CSR is measured as one of the CSR disclosure measures (IntRep, GRI, and CompDisc) or the CSR assurance measures (ASSdum, ASSscope and CompAss) that are separately included in the regression. Size is measured as the natural logarithm of the company's market capitalisation. Stock turnover is calculated as the annual share turnover in the underlying stock over the applicable sample periods. ROA is measured as net income deflated by total assets. Capital_ expenditure is measured as capital expenditure deflated by total assets. Debt is measured as total debt deflated by total assets. Dividends is an indicator variable set to 1 if the company paid a dividend in the applicable year, and to 0 if that is not the case. Intangible_assets are measured as the difference between 1 and the ratio of net property, plant and equipment to total assets. R\&D is an indicator variable set to 1 if the company's research and development intensity ( $R \& D$ deflated by total assets) is greater than the 75th percentile value of the sample companies, and otherwise to 0 . Return_volatility is the annualised volatility close measure over the applicable sample periods. Based on hypothesis 1 , we expect $\beta_{1}$ to be positively and significantly associated with firm value for the measures of CSR disclosure and, based on hypothesis 2 , to not be associated with firm value for the three measures of CSR assurance. We control for year fixed effects by including the variable, Yr.

\section{Additional analysis}

Future cash flow and future profitability: We examine whether higher levels of CSR reporting, including disclosure or obtaining third-party assurance of the CSR report, are associated with realised financial consequences as reflected in future cash flow and future profitability. The examination of future cash flow and future profitability is useful for obtaining a better understanding of the firm value component driving the expected value and the future realisation of market participants' expectations. Future firm cash flow and future firm profitability reflect the consequences of current CSR initiatives on actual (versus expected) future cash flow and future profitability (Cahan et al. 2016). In order to explore whether CSR reporting is associated with future cash flow and profitability, we regress the average operating cash flow (AVECFO) and the average return on assets AVEROA as the dependent variable on the control variables (Clarkson et al. 2013) and each of the six measures of CSR reporting separately.

To explore the association between CSR reporting (both CSR disclosure and CSR assurance), and future cash flow and future profitability, we follow Clarkson et al. (2013) and estimate the following regressions: $\operatorname{AVECFO}_{\mathrm{i}, t+1,2,3,4,5}=\beta_{0}+$ $\beta_{1} \mathrm{CSR}_{\mathrm{i}, \mathrm{t}}+\beta_{2} \mathrm{CFO}_{\mathrm{i}, \mathrm{t}}+\beta_{3} \mathrm{Size}_{\mathrm{i}, \mathrm{t}}+Y_{r}+\varepsilon_{\mathrm{i}, \mathrm{t}}$

AVECFO is measured as the average cash flow from operations one to five years ahead for the 2008 CSR measures, the average cash flow from operations one to three years ahead for the 2011 CSR measures, and the average cash flow 
from operations one year ahead for the 2013 CSR measures. CSR is measured and included as discussed in the 'Firm value' section. In the above regression, when the CSR assurance measures are separately included as CSR, we address the possibility that disclosure may have a significant effect on assurance by including GRI and CompDisc as control variables for disclosure. CFO is measured as operating cash flow scaled by total assets. Size is measured as the log of the company's market value at the end of the applicable financial year. We include indicator variables to control for the year-fixed effects (Yr). AVEROA $A_{i, t+1,2,3,4,5}=\beta_{0}+\beta_{1} \operatorname{CSR}_{\mathrm{i}, \mathrm{t}}+$ $\beta_{2}$ ROA $_{i, t}+\beta_{3}$ Size $_{i, t}+Y r+\varepsilon_{i, t^{*}}$

$A V E R O A$ is measured as the average return on assets one to five years ahead for the 2008 CSR measures, the average return on assets one to three years ahead for the 2011 CSR measures, and the average return on assets one year ahead for the 2013 CSR measures. CSR is measured and included as discussed in the 'Firm value' section. ROA is measured as the net operating income divided by total assets at the beginning of the year. Size and the indicator variables are measured and included as discussed above.

Sensitive industries: Following the example set by De Klerk et al. (2015), we examine whether there is a difference between companies in environmentally sensitive industries and companies in other industries with regard to the association between CSR reporting, including both CSR disclosure and CSR assurance, and firm value. An indicator variable for environmentally sensitive industries (ES) and an interaction variable between CSR reporting and environmentally sensitive industries (ES*CSR) are incorporated. The indicator variable (ES) is set to 1 if a company operates in an environmentally sensitive industry, and otherwise to 0 . ES and ES*CSR are not deflated as they are regarded as independent of firm size. We expect the association on the interaction variable to differ significantly between companies in environmentally sensitive industries and companies in other industries.

Control for Socially Responsible Investment index: We attempt to control for the possibility that shareholders know the financial and environmental performance of the company and that the association previously tested between CSR reporting and firm value is actually due to the company's CSR performance (Clarkson et al. 2013). The Clarkson et al. (2013) study uses the Toxics Releases Inventory (TRI) as a proxy for environmental performance. Since no such index exists in South Africa, we use the SRI index as a proxy for CSR performance (Jordaan, De Klerk \& De Villiers 2018).
We attempt to control companies' CSR performance by including the SRI index rating as a control variable and performing the main analysis regressions on a segregated sample. The control variable (SRI) is an indicator variable that is set to 1 for companies listed on the SRI index, and otherwise to 0 . The segregated sample analysis is performed by dividing the total sample into two separate samples based on the company's inclusion in the SRI index.

\section{Results \\ Descriptive statistics}

Table 1 depicts the overall descriptive statistics in terms of the number of companies that use the GRI guidelines, that provide third-party assurance statements, and that are included in the SRI index. The percentage of companies that use the GRI guidelines has increased from $43 \%$ of the sample companies in 2008 to $65 \%$ in 2011 and $83 \%$ in 2013. The percentage of companies that provide a formal third-party assurance statement has also increased significantly from only $13 \%$ of the sample companies in 2008 to $27 \%$ in 2011 and $38 \%$ in 2013 . The number of sample companies categorised as environmentally sensitive (ES) has remained comparable in the different sample periods (De Villiers, Naiker \& Van Staden 2011). Table 2 depicts the descriptive statistics for the variables included in the equations.

The dependent variable in Table 2 is Tobin's $Q$ with the variables of interest in Table 2 being the CSR measures for CSR disclosure and CSR assurance. The control variables in Table 2 are: (1) Size, natural logarithm of the company's market capitalisation; (2) Stock_turnover, annual share turnover in the underlying stock over the applicable sample periods; (3) ROA, net income deflated by total assets; (4) Capital_expenditure, capital expenditure deflated by total assets; (5) Debt, total debt deflated by total assets; (6) Dividends, indicator if the company paid a dividend in the applicable year; (7) Intangible_assets, difference between 1 and the ratio of net property, plant and equipment to total assets; (8) R\&D, indicator if the company's research and development intensity - R\&D deflated by total assets - is greater than the 75th percentile value of the sample companies; and (8) Return_volatility, annualised volatility close measure over the applicable sample periods.

\section{Regression results for firm value}

We expect the measures of CSR disclosure to be positively and significantly associated with firm value $(\mathrm{H} 1)$, while no association is expected between CSR assurance and firm value.

TABLE 1: Descriptive statistics for the sample.

\begin{tabular}{|c|c|c|c|c|c|c|c|c|}
\hline \multirow[t]{2}{*}{ Variable } & \multicolumn{2}{|c|}{2008} & \multicolumn{2}{|c|}{2011} & \multicolumn{2}{|c|}{2013} & \multicolumn{2}{|c|}{ Total } \\
\hline & $n$ & $\%$ & $n$ & $\%$ & $n$ & $\%$ & $n$ & $\%$ \\
\hline Observations & 65 & - & 75 & - & 73 & - & 213 & - \\
\hline GRI guidelines & 29 & 45 & 47 & 63 & 60 & 82 & 136 & 64 \\
\hline Provided a formal assurance statement by a third-party & 9 & 14 & 19 & 25 & 27 & 37 & 55 & 26 \\
\hline Included on the SRI index & 31 & 48 & 38 & 51 & 35 & 48 & 104 & 48 \\
\hline Categorised as environmentally sensitive & 18 & 28 & 20 & 27 & 18 & 25 & 56 & 26 \\
\hline
\end{tabular}

SRI, Socially Responsible Investment; GRI, Global Reporting Initiative. 
TABLE 2: Descriptive statistics for regression models.

\begin{tabular}{|c|c|c|c|c|c|}
\hline Variable of interest & Mean & Median & Standard deviation & Minimum & Maximum \\
\hline \multicolumn{6}{|l|}{ CSR reporting measures } \\
\hline IntRep & 1.610 & 2.000 & 0.919 & 0.000 & 3.000 \\
\hline GRI & 0.640 & 1.000 & 0.481 & 0.000 & 1.000 \\
\hline CompDisc & 2.110 & 2.000 & 0.956 & 0.000 & 4.000 \\
\hline ASSdum & 0.260 & 0.000 & 0.440 & 0.000 & 1.000 \\
\hline ASSscope & 0.370 & 0.000 & 0.757 & 0.000 & 3.000 \\
\hline CompAss & 0.720 & 0.000 & 1.309 & 0.000 & 5.000 \\
\hline \multicolumn{6}{|c|}{ Control variable for CSR performance } \\
\hline SRI index constituents & 0.490 & 0.000 & 0.501 & 0.000 & 1.000 \\
\hline \multicolumn{6}{|c|}{ Tobin's Q model: Dependent variable } \\
\hline Q & 1.932 & 1.577 & 1.200 & 0.368 & 9.794 \\
\hline \multicolumn{6}{|l|}{ Control variables } \\
\hline Size & 16.531 & 16.322 & 1.542 & 11.300 & 20.581 \\
\hline Stock_turnover & 0.605 & 0.516 & 0.440 & 0.003 & 3.023 \\
\hline Capital_expenditure & 0.076 & 0.066 & 0.047 & 0.000 & 0.289 \\
\hline Debt & 0.109 & 0.074 & 0.122 & 0.000 & 0.779 \\
\hline Dividends & 0.859 & 1.000 & 0.349 & 0.000 & 1.000 \\
\hline Intangible_assets & 0.705 & 0.729 & 0.191 & 0.183 & 1.000 \\
\hline$R \& D$ & 0.873 & 1.000 & 0.333 & 0.000 & 1.000 \\
\hline Return_volatility & 0.286 & 0.275 & 0.091 & 0.000 & 0.799 \\
\hline
\end{tabular}

CSR, Corporate Social Responsibility; IntRep, Level of integration of CSR reporting; GRI, Global Reporting Initiative; CompDisc, Composite measure of CSR disclosure; ASSdum, Indicator of CSR assurance; ASSscope, Assurance statement scope; CompAss, Composite measure of CSR assurance; SRI, Socially Responsible Investment; Q, Tobin's Q; R\&D, Research and development intensity.

The regression results for Tobin's $Q$ are presented in Table 3 (CSR disclosure) and Table 4 (CSR assurance).

The dependent variable in Table 3 and 4 is Q which is Tobin's $\mathrm{Q}$ measured as the market value of assets (sum of the book value of assets and the market value of common stock, less the book value of common stock and book value of deferred taxes) deflated by the book value of total assets.

CSR measures CSR disclosure as IntRep, GRI, or CompDisc, separately included in the regression. Size is measured as the natural logarithm of the company's market capitalisation. Stock_turnover is calculated as the annual share turnover in the underlying stock over the applicable sample periods. ROA is measured as net income deflated by total assets. Capital_expenditure is measured as capital expenditure deflated by total assets. Debt is measured as total debt deflated by total assets. Dividends is an indicator variable set to 1 if the company paid a dividend in the applicable year, and to 0 if that is not the case. Intangible_assets are measured as the difference between 1 and the ratio of net property, plant and equipment to total assets. R\&D is an indicator variable set to 1 if the company's research and development intensity ( $R \& D$ deflated by total assets) is greater than the 75 th percentile value of the sample companies, and otherwise to 0 . Return_volatility is the annualised volatility close measure over the applicable sample periods. Year fixed effects are controlled for by including the variable, $Y r$.

The significance of Table 3 and 4 is two-tailed, except for the variables of interest, which are one-tailed.

IntRep, GRI and CompDisc are positively and not significantly associated with firm value. The insignificant result for the
TABLE 3: Regression results for firm value - corporate social responsibility disclosure measures.

\begin{tabular}{lccc}
\hline Variable & IntRep & GRI & CompDisc \\
\hline Intercept & $-1.721^{*}$ & $-1.637^{*}$ & $-1.717^{*}$ \\
Variables of interest & & & \\
CSR $_{\mathrm{i}, \mathrm{t}}$ & 0.018 & 0.129 & 0.007 \\
Control variables & & & \\
Size $_{\mathrm{i}, \mathrm{t}}$ & $0.143^{* *}$ & $0.135^{* *}$ & $0.143^{* *}$ \\
Stock_turnover $_{\mathrm{i}, \mathrm{t}}$ & 0.079 & 0.044 & 0.078 \\
ROA $_{\mathrm{i}, \mathrm{t}}$ & $5.480^{* *}$ & $5.492^{* *}$ & $5.472^{* *}$ \\
Capital_expenditure $_{\mathrm{i}, \mathrm{t}}$ & 1.031 & 0.911 & 1.040 \\
Debt $_{\mathrm{i}, \mathrm{t}}$ & -0.292 & -0.270 & -0.294 \\
Dividends & -0.039 & -0.043 & -0.039 \\
Intangible_assets $_{\mathrm{i}, \mathrm{t}}$ & 0.442 & 0.500 & 0.448 \\
R\&D $_{\mathrm{i}, \mathrm{t}}$ & 0.265 & 0.293 & 0.273 \\
Return_volatility $_{\mathrm{i}, \mathrm{t}}$ & -0.525 & -0.595 & -0.537 \\
Yr indicators & Included in all & Included in all & Included in all \\
Number of observations & regressions & regressions & regressions \\
\hline
\end{tabular}

Note: $Q_{i, t}=\beta_{0}+\beta_{1} C R_{i, t}+\beta_{2}$ Size $_{i, t}+\beta_{3}$ Stock_turnover $_{i, t}+\beta_{4} R_{\text {ROA }}+\beta_{5}$ Capital_expenditure $_{i, t}+$ $\beta_{6}$ Debt $_{1, t}+\beta_{7}$ Dividends $_{\text {it }}+\beta_{8}$ Intangible_assets $+\beta_{9} R \& D_{i, t}+\beta_{10}$ Return_volatility $_{i, t}+Y r+\varepsilon$ $*, 10 \%$ significance; $* *, 1 \%$ significance.

CSR, corporate social responsibility; ROA, Return on assets; R\&D, research and development intensity; $\mathrm{Yr}$, year-fixed effects, ${ }_{\mathrm{i}, \mathrm{t}^{\prime}}$ for company $i$ for period $t$.

CSR disclosure measures suggests that firm value is unaffected by CSR disclosures, consistent with these CSR disclosures having become regulated and routine and providing limited incremental information beyond other companies' CSR disclosures. The results are in line with the finding of Cahan et al. (2016) on the expected portion of CSR disclosures.

We find the coefficient on size and return on assets are positively signed and significant at the $1 \%$ level. This indicates that firm value is significantly affected by the size and profitability of the company.

The CSR assurance measures are negatively associated with firm value. The association of two of the three CSR assurance 
TABLE 4: Regression results for firm value - corporate social responsibility assurance measures controlling for disclosure.

\begin{tabular}{|c|c|c|c|}
\hline Variable & ASSdum & ASSscope & CompAss \\
\hline Intercept $\mathrm{i}_{\mathrm{i}, \mathrm{t}}$ & $-2.072 * *$ & $-1.794 *$ & $-1.955 * *$ \\
\hline \multicolumn{4}{|l|}{ Variable of interest } \\
\hline $\mathrm{CSR}_{\mathrm{i}, \mathrm{t}}$ & $-0.345 * *$ & -0.128 & $-0.108 * *$ \\
\hline \multicolumn{4}{|l|}{ Control variables } \\
\hline Size $_{i, t}$ & $0.161 * * *$ & $0.150 * * *$ & $0.033 * * *$ \\
\hline Stock_turnover ${ }_{i, t}$ & 0.045 & 0.023 & 5.343 \\
\hline $\mathrm{ROA}_{\mathrm{i}, \mathrm{t}}$ & $5.386 * * *$ & $5.428 * * *$ & $0.960 * * *$ \\
\hline Capital_expenditure ${ }_{i, t}$ & 1.069 & 0.822 & -0.346 \\
\hline Debt $_{\mathrm{i}, \mathrm{t}}$ & -0.310 & -0.298 & 0.003 \\
\hline Dividends $_{\mathrm{i}, \mathrm{t}}$ & 0.012 & -0.011 & 0.384 \\
\hline Intangible_assets ${ }_{\mathrm{i}, \mathrm{t}}$ & 0.400 & 0.418 & 0.189 \\
\hline$R \& D_{i, t}$ & 0.222 & 0.245 & -0.350 \\
\hline Return_volatility $_{\mathrm{i}, \mathrm{t}}$ & -0.279 & -0.476 & 0.033 \\
\hline $\mathrm{GRI}_{\mathrm{i}, \mathrm{t}}$ & 0.176 & 0.168 & 0.177 \\
\hline CompDisc $_{i, t}$ & 0.013 & 0.000 & 0.003 \\
\hline Yr indicators & $\begin{array}{l}\text { Included in all } \\
\text { regressions }\end{array}$ & $\begin{array}{l}\text { Included in all } \\
\text { regressions }\end{array}$ & $\begin{array}{l}\text { Included in all } \\
\text { regressions }\end{array}$ \\
\hline Number of observations & 213 & 213 & 213 \\
\hline \multicolumn{4}{|c|}{ 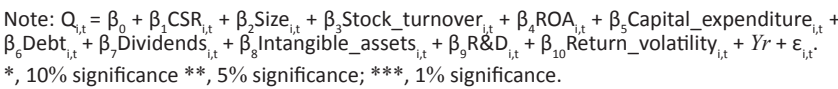 } \\
\hline \multicolumn{4}{|c|}{$\begin{array}{l}\text { CSR, corporate social responsibility; ROA, Return on assets; R\&D, research and development } \\
\text { intensity; GRI, Global Reporting Initiative; CompDisc, composite measure; Yr, year-fixed } \\
\text { effects, }{ }_{\mathrm{i}, \mathrm{t}^{\prime}} \text { for company } i \text { for period } t \text {. }\end{array}$} \\
\hline
\end{tabular}

measures, namely ASSdum and CompAss, are significant at the 5\% level. The significant negative result for these CSR assurance measures suggests that managers may choose to obtain assurance of the sustainability report in an attempt to enhance the CSR credibility of the company, consistent with the choice to provide CSR assurance being positively associated with the need to enhance the credibility of the CSR report. The results are in line with the finding of Simnett et al. (2009) that companies with pre-existing issues with credibility are more likely to obtain CSR assurance.

Similar to the regression results for the CSR disclosure measures, we find that firm value is significantly affected by the size and profitability of the company.

The variance inflation factors (VIFs) of all the variables included in the main analysis range from 1.228 to 6.691 , which are well below the standard benchmark of 10 (De Villiers \& Marques 2016).

In summary, the results suggest that there is no significant association between CSR disclosure and firm value. The association between ASSdum and CompAss and firm value is negative and significant.

\section{Results of additional analysis}

\section{Regression results for future cash flow and future profitability}

The untabulated results suggest that there is no significant association between CSR reporting and future cash flow, as IntRep, GRI, and CompDisc are not significantly associated with future cash flow and the coefficients for the CSR assurance measures are not significantly associated with future cash flow.
CSR disclosure is not significantly associated with future profitability. The measures of CSR assurance are negatively associated with future profitability in period $t_{+1}, t_{+4}$ and $t_{+5}$. The negative association for ASSdum is significant at the $10 \%$ and $5 \%$ levels for periods $t_{+2}$ and $t_{+3}$ respectively, ASSscope is significant at the $10 \%$ level for both periods $t_{+1}$ and $t_{+3^{\prime}}$ and CompAss is significant at the $10 \%$ and $5 \%$ levels for periods $t_{+2}$ and $\mathrm{t}_{+3}$ respectively.

In summary, the results suggest that while there is no significant association between CSR disclosure and future profitability, the three CSR assurance measures do have a significantly negative association with future profitability after three years (and some of the prior years).

\section{Sensitive industries}

CSR disclosure is not found to differ significantly between companies in environmentally sensitive industries and companies in other industries.

However, in terms of CSR assurance, the coefficient for the interaction term $(\mathrm{ES} * \mathrm{CSR})$ is negative and significant at the $10 \%$ level (ASSdum is significant at $5 \%$ ), indicating a significant difference between companies in environmentally sensitive industries and those in other industries. The results are untabulated.

\section{Control for Socially Responsible Investment index}

The untabulated results for the analysis of firm value when SRI is included as a control for CSR performance remain qualitatively similar for the CSR disclosure and assurance measures. Finally, the results for the analysis of firm value when the sample is segregated indicate that the association between firm value and the CSR disclosure measures is not significant for both SRI index-listed and non-listed companies, with the exception of a positive association between GRI and firm value for companies listed on the SRI index, which is significant at the $10 \%$ level. The CSR assurance measures remain negatively associated with firm value for both SRI index-listed and non-listed companies. The association between ASSdum and CompAss and firm value is significant at the $10 \%$ level for companies listed on the SRI index. The association between ASSdum, and CompAss and firm value is significant at between $1 \%$ and $5 \%$ for companies not listed on the SRI index.

\section{Conclusion}

We conduct an analysis to evaluate whether higher levels of CSR reporting are associated with firm value (using Tobin's $Q$ as measure of firm value) of large South African companies. We argue that managers have an incentive to provide higher levels of CSR disclosure to enable better prediction of future cash flow and future profitability associated with the future competitive advantage obtained through their CSR activities (Clarkson et al. 2013). We further argue that increased CSR disclosure will reduce information asymmetries between managers and shareholders, which will increase firm value. 
Therefore, CSR disclosure levels are expected to be positively associated with firm value (H1). Companies (managers) may choose to obtain third-party assurance of their CSR reports either to signal credibility to the market, or to mask credibility issues from the market. Inconsistencies in the assurance market may; however, limit the effect assurance has on enhancing the credibility of the disclosure (Deegan et al. 2006). Therefore, no expectations are formed with regard to the direction of the association between the CSR assurance measures and firm value (H2).

We do not find evidence of a significant association between CSR disclosure and firm value. The results, therefore, do not support H1, which may indicate a weakening of the association between CSR disclosures and financial consequences as CSR disclosure is becoming more regulated and routine and supports the findings of Marcia, Maroun and Callaghan (2015) that corporate responsibility reporting may not add value in a South African setting. The results are robust when controlling for companies on the SRI index. The regression results of $\mathrm{H} 2$ find the association between ASSdum and CompAss and firm value to be significantly negative. The negative association between firm value and CSR assurance is more significant for companies not listed on the SRI index. Given the limitation of the relatively small group of companies that provide CSR assurance during the sample period, the results suggest that South African companies (managers) with negative CSR issues are more likely to obtain and provide assurance on their CSR disclosure. The results can potentially be explained by the findings of Simnett et al. (2009). Simnett et al. (2009) conclude that the choice to provide CSR assurance is positively associated with the need to enhance the credibility of the CSR report, and likely to be obtained when companies have preexisting issues with credibility.

We contribute to the literature by being, to our knowledge, the first researchers to examine the association between firm value and CSR disclosure and CSR assurance in South Africa. South Africa provides an ideal setting in which to explore and gain an understanding of CSR practices, as it is at the forefront of mandating both CSR disclosure and the assurance thereof. Our separate investigations of the trends in CSR disclosure and CSR assurance contribute to the literature by addressing the possible contrasting effects of these separate management choices. We further contribute by investigating whether the association with firm value differs between companies listed on the SRI index and companies not listed on the SRI index.

Our research findings may be of interest to regulators in other countries who are considering legislation around CSR reporting. Our results are indicative of a possible weakening of the association between CSR disclosures and firm value, which contrasts with the mostly positive association documented in the relevant literature (Cahan et al. 2016; Jiao 2010, 2011). The significant negative association found between CSR assurance and firm value may further interest regulators when considering mandating assurance of the CSR report.
It may not be possible to generalise our study to smaller companies and companies in countries where CSR reporting is not mandated. Regulatory requirements potentially affect both managers' decision to disclose CSR and obtain assurance of the CSR report, and stakeholders' assessment thereof. In light of the small sample size, the results for obtaining assurance of the CSR report should be interpreted with caution. Our CSR reporting measures have a limited scope and do not represent comprehensive measures of CSR reporting, as only certain aspects of disclosure and assurance are included. Furthermore, our study does not test the association between CSR reporting and the financial consequences separately for the sample years. Future research could examine the period effect and the change, if any, in the association between firm value and CSR reporting over time, in order to gain an understanding of the effect of increased public awareness of corporate responsibility and the effect of regulation on the communication and assurance of companies' CSR activities. A continuation of the investigation of the association between assurance of the CSR report and the financial consequences thereof on a larger sample and across different settings could be another avenue for future research. The increasing trend for companies to provide CSR assurance may result in more archival data becoming available and warrant an analysis of whether the level and the scope of CSR assurance provided are associated with firm value, share price, and other measures of financial performance.

\section{Acknowledgements Competing interests}

The views expressed in the submitted article are not an official position of the institution. The authors declare that they have no financial or personal relationships that may have inappropriately influenced them in writing this article.

\section{Authors' contributions}

R.H. was responsible for generating the research objective, gathering the data, performing the analyses, concluding and writing the article. M.d.K. and C.d.V. were involved in providing guidance throughout the process.

\section{References}

Al-Tuwaijri, S.A., Christensen, T.E. \& Hughes II, K.E., 2004, 'The relations among environmental disclosure, environmental performance, and economic performance: A simultaneous equations approach', Accounting, Organizations and Society 29, A simultaneous equations approach', Accounting, Organizatic
447-471. https://doi.org/10.1016/S0361-3682(03)00032-1

Cahan, S.F., De Villiers, C., Jeter, D.C., Naiker, V. \& Van Staden, C.J., 2016, 'Are CSR Disclosures value Relevant? Cross-Country evidence', European Accounting Review 25(3), 579-611. https://doi.org/10.1080/09638180.2015.1064009

Choi, J., Kwak, Y. \& Choe, C., 2010, 'Corporate social responsibility and corporate financial performance: Evidence from Korea', Australian Journal of Management 35(3), 291-311. https://doi.org/10.1177/0312896210384681

Clarkson, P.M., Fang, X., Li, Y. \& Richardson, G., 2013, 'The relevance of environmental disclosures: Are such disclosures incrementally informative?', Journal of Accounting and Public Policy 32(5), 410-431. https://doi.org/10.1016/j.jaccpubpol.2013.06.008

Clarkson, P.M., Li, Y., Richardson, G.D. \& Vasvari, F.P., 2008, 'Revisiting the relation between environmental performance and environmental disclosure: An empirical analysis', Accounting, Organizations and Society 33(3), 303-327. https://doi.org/ 10.1016/j.aos.2007.05.003

Coles, J.L., Daniel, N.D. \& Naveen, L., 2008, 'Boards: Does one size fit all?', Journal of Financial Economics 87, 329-356. https://doi.org/10.1016/j.jfineco.2006.08.008 
Deegan, C., Cooper, B.J. \& Shelly, M., 2006, 'An investigation of TBL report assurance statements: UK and European evidence', Managerial Auditing Journal 21(4) 329-371. https://doi.org/10.1108/02686900610661388

De Klerk, M. \& De Villiers, C., 2012, 'The value relevance of corporate responsibility reporting: South African evidence', Meditari Accountancy Research 20(1), 21-38. https://doi.org/10.1108/10222521211234200

De Klerk, M., De Villiers, C. \& Van Staden, C., 2015, 'The influence of corporate social responsibility disclosure on share price: Evidence from the United Kingdom', Pacific Accounting Review 27(2), 208-228. https://doi.org/10.1108/PAR-05-2013-0047

De Villiers, C., Hsiao, P.-C.K. \& Maroun, W., 2017, 'Developing a conceptual model of influences around integrated reporting, new insights, and directions for future research', Meditari Accountancy Research 25(4), 450-460. https://doi.org/ 10.1108/MEDAR-07-2017-0183

De Villiers, C. \& Marques, A., 2016, 'Corporate social responsibility, country-level predispositions, and the consequences of choosing a level of disclosure', Accounting and Business Research 46(2), 167-195.

De Villiers, C., Naiker, V. \& Van Staden, C.J., 2011, 'The effect of board characteristics on firm environmental performance', Journal of Management 37(6), 1636-1663. https://doi.org/10.1177/0149206311411506

De Villiers, C. \& Van Staden, C., 2010, 'Shareholders' corporate environmental disclosure needs', South African Journal of Economic and Management Sciences 13(4), 437-446. https://doi.org/10.4102/sajems.v13i4.99

De Villiers, C. \& Van Staden, C.J., 2011a, 'Where firms choose to disclose voluntary environmental information', Journal of Accounting and Public Policy 30, 504-525. https://doi.org/10.1016/j.jaccpubpol.2011.03.005

De Villiers, C. \& Van Staden, C.J., 2011b, 'Shareholder requirements for compulsory environmental information in Annual Reports and on Websites', Australian Accounting Review 21(4), 317-326. https://doi.org/10.1111/j.1835-2561.2011. 00144.x

Dhaliwal, D.S., Li, O.Z., Tsang, A. \& Yang, Y.G., 2011, 'Voluntary nonfinancial disclosure and the cost of equity capital: The initiation of corporate social responsibility reporting' The Accounting Review 86(1), 59-100. https://doi.org/10.2308/accr.00000005

Dhaliwal, D., Li, O.Z., Tsang, A. \& Yang, Y.G., 2014, 'Corporate social responsibility disclosure and the cost of equity capital: The roles of stakeholder orientation and financial transparency', Journal of Accounting and Public Policy 33, 328-355.

Du Toit, E., Van Zyl, R. \& Schutte, G., 2017, 'Integrated reporting by South African companies: A case study', Meditari Accountancy Research 25(4), 654-674. https:// doi.org/10.1108/MEDAR-03-2016-0052

Dumay, J., Bernardi, C., Guthrie, J. \& La Torre, M., 2017, 'Barriers to implementing the International Integrated Reporting Framework: A contemporary academic perspective', Meditari Accountancy Research 25(4), 461-480. https://doi.org/ 10.1108/MEDAR-05-2017-0150

Dumay, J. \& Dai, T., 2017, 'Integrated thinking as a cultural control?', Meditar Accountancy Research 25(4), 574-604. https://doi.org/10.1108/MEDAR-072016-0067

Jiao, Y., 2010, 'Stakeholder welfare and firm value', Journal of Banking and Finance 34, 2549-2561. https://doi.org/10.1016/j.jbankfin.2010.04.013

Jiao, Y., 2011, 'Corporate disclosure, market valuation, and firm performance', Financia Management 40(3), 647-676. https://doi.org/10.1111/j.1755-053X.2011.01156.x

Jordaan, L.A., De Klerk, M. \& De Villiers, C.J., 2018, 'Corporate social responsibility and earnings management of South African companies', South African Journal of Economic and Management Sciences, 21(1), 1849. https://doi.org/10.4102/ sajems.v21i1.1849
JSE, 2013a, Regulation, viewed 19 September 2015, from https://www.jse.co.za/ about/sustainability/regulator-influencer-advocate

JSE, 2013b, Guidance letter integrated reporting, viewed 12 November 2017, from https://www.jse.co.za/content/JSEGuidanceLettersItems/Guidance\%20Letter $\% 20$ Integrated\%20Reporting\%20June\%202013.pd

JSE, 2014, Socially responsible investment index, viewed 16 April 2018, from https:// www.jse.co.za/services/market-data/indices/socially-responsible-investmentindex

Kamala, P.N., Wingard, C. \& Cronje, C., 2016, 'Users' corporate environmental information needs', South African Journal of Economic and Management Sciences 19(4), 579-591. https://doi.org/10.4102/sajems.v19i4.1312

King Committee, 2009, King Report on Governance for South Africa, Institute of Directors in Southern Africa, Johannesburg.

KPMG, 2008, International Survey of Corporate Responsibility Reporting, viewed 13 March 2014, from http://www.kpmg.com/EU/en/Documents/KPMG_International survey_Corporate-responsibility_Survey_Reporting_2008.pdf

KPMG, 2011, International survey of corporate responsibility reporting, viewed 13 March 2014, from http://www.kpmg.com/global/en/issuesandinsights/ articlespublications/corporate-responsibility/pages/2011-survey.aspx

KPMG, 2013, International survey of corporate responsibility reporting, viewed 04 March 2014, from http://www.kpmg.com/global/en/issuesandinsights/ articlespublications/corporate-responsibility/pages/corporate-responsibilityreporting-survey-2013.aspx

Marcia, A., Maroun, W. \& Callaghan, C., 2015, 'Value relevance and corporate responsibility reporting in the South African context: An alternative view post King-III', South African Journal of Economic and Management Sciences 18(4), 500-518. https://doi.org/10.4102/sajems.v18i4.1192

Macias, H.A. \& Farfan-Lievano, A., 2017, 'Integrated reporting as a strategy for firm growth: Multiple case study in Colombia', Meditari Accountancy Research 25, 605-628. https://doi.org/10.1108/MEDAR-11-2016-0099

McNally, M.-A., Cerbone, D. \& Maroun, W., 2017, 'Exploring the challenges of preparing an integrated report', Meditari Accountancy Research 25(4), 481-504. https://doi.org/10.1108/MEDAR-10-2016-0085

O'Dwyer, B. \& Owen, D.L., 2005, 'Assurance statement practice in environmental, social and sustainability reporting: A critical evaluation', The British Accounting Review 37, 205-229. https://doi.org/10.1016/j.bar.2005.01.005

Park, J. \& Brorson, T., 2005, 'Experiences of and views on third-party assurance of corporate environmental and sustainability reports', Journal of Cleaner Production 13, 1095-1106. https://doi.org/10.1016/j.jclepro.2004.12.006

Reverte, C., 2012, 'The impact of better corporate social responsibility disclosure on the cost of equity capital', Corporate Social Responsibility and Environmental Management 19, 253-272. https://doi.org/10.1002/csr.273

Roll, R., Schwartz, E. \& Subrahmanyam, A., 2009, 'Options trading activity and firm valuation', Journal of Financial Economics 944, 345-360.

Simnett, R., Vanstraelen, A. \& Chua, W.F., 2009, 'Assurance on sustainability reports: An international comparison', The Accounting Review 84(3), 937-967. https://doi. org/10.2308/accr.2009.84.3.937

Turyakira, P., Venter, E. \& Smith, E., 2014, 'The impact of corporate social responsibility factors on the competitiveness of small and medium-sized enterprises', South African Journal of Economic and Management Sciences 17(1), 157-172. https:// doi.org/10.4102/sajems.v17i2.443 